\title{
Communication and functioning of pupils with autism in public school three case studies
}

\begin{abstract}
Ewelina Zając, Communication and functioning of pupils with autism in public school - three case studies. Interdisciplinary Contexts of Special Pedagogy, no. 24, Poznań 2019. Pp. 139-153. Adam Mickiewicz University Press. ISSN 2300-391X. DOI: https://doi.org/10.14746/ikps.2019.24.08

The purpose of this article is to characterize the means of communication of three autistic pupils with their teachers and peers as well as their daily functioning in the community of one of the public schools located in the Wielkopolska region of Poland.
\end{abstract}

KEY WORDS: autism, logopedics, therapy, communication skills, social skills training

\section{Foreword}

(...) to have autism - to be autistic - represents but one more wrinkle in the fabric of humanity and no one among us is living a life 'unwrinkled'1.

A lot has already been written about autism, and the perception of persons on the autism spectrum has dramatically changed over

${ }^{1}$ J. Donvan, C. Zucker, Wedtug innego klucza. Opowieść o autyzmie, Wydawnictwo Uniwersytetu Jagiellońskiego, Kraków 2017, p. 523. 
the last decades. In time, the attitude to persons considered to be autistic has improved, and contempt and cruelty are now a thing of the past. Now, it is believed that these persons should be considered as one of us and they should be granted an equal share in the world. 77 years have passed since the first child was diagnosed with autism disorders. Many therapeutic and educational methods and techniques have developed to improve the most defective functions in persons on the autism spectrum. Every person is different, and the same is true for a person with autistic disorders, especially a child pupil. The education process emphasizes individualization of teaching and each programme, therapy or method must be tailored to the needs of a specific child, and nothing must be imposed externally.

The educational success of every child depends on his or her teachers accepting and understanding their problems. Also, the success of a pupil with autism spectrum disorders requires acceptance of the fact that he or she will require more engagement, help and support from the teachers than other pupils. However, the teacher faces not only the challenge of supporting such a pupil in the teaching process and tailoring the teaching methods to his or her needs but also of stimulating his or her social integration and preventing emotional disorders by protecting him or her against the rejection and violence of peers ${ }^{2}$ The organization of classwork is also important - teachers should remember to maintain an appropriate scheme of work and repetitiveness of activities, as pupils on the autism spectrum function better when they know the lesson plan and are not surprised by changes.

The educational process should be accommodated to children on the autism spectrum so as to enable their full development and not to cause fear and frustration. The teaching process should be developed on the basis of the strengths of pupils with autism spectrum disorders as well as on such features as: problems with atten-

${ }^{2}$ G. Jagielska, Dziecko $z$ autyzmem $i$ zespotem Aspergera w szkole i przedszkolu, Ośrodek Rozwoju Edukacji, Warszawa 2010, p. 17. 
tion, motor disorders, perceptive disorders or pedantry3 ${ }^{3}$. Persons on the autism spectrum usually have disordered social interactions, communication (bilateral verbal and non-verbal communication) and recurring, limited and stereotypical patterns of behavior, interests and activities. These functions need to be improved throughout the entire education process - both in and out of school.

\section{Purpose of research and methodology}

In order to conduct scholarly research, it is necessary to determine its purpose and scope. The purpose is "the type of intended effect that the research is supposed to lead to" 4 The purpose of the article is to characterize communication between three pupils with autism spectrum disorders and their peers and teachers, and their daily life functioning in the school community. The three pupils attend one of the public schools (primary and junior high school) in the Wielkopolskie region of Poland. The article is intended to show the importance of cooperation between the respective professional who work with a child. It does not focus on a specific therapeutic method, but rather presents the therapeutic process holistically.

In order for scholarly research to be reliable, it is important to select proper research methods, techniques and tools to achieve the purpose of the research and take measures to solve the scholarly problem. Logopedics draws on many disciplines: linguistics, pedagogy, special pedagogy, medicine; it does not have its own methodology, so it often uses the methodological foundations of linguistics,

${ }^{3}$ E. Januszewska, I. Januszewska, Stymulacja rozwoju zdolności i zainteresowań u ucznia z zespotem Aspergera, [in:] Osoba ze stanami ze spektrum autyzmu. Możliwości aktywnego życia, ed. J. Kossewska, Wydawnictwo JAK, Kraków 2014, p. 116.

${ }^{4} \mathrm{~J}$. Gnitecki, Zarys metodologii badań w pedagogice empirycznej, Wydawnictwo Wyższej Szkoły Pedagogicznej im. Tadeusza Kotarbińskiego, Zielona Góra 1993, p. 127. 
pedagogy or biology 5 . This article presents three case studies, it being the only way to closely pupils on the autism spectrum and their linguistic and social behaviors. The case study is a method that, thanks to its individual nature, makes it possible to explore the internal structure of the studied phenomenon, processes and behaviors, and the external conditions of the behavior of the object of the study; its goal is to describe in detail and in a reliable manner the object of the study, taking into account various factors and aspects 6 . One of the most frequent research methods is observation, which proved ideal in the study on the communication behavior of children on the autism spectrum.

The pupils presented in the case study come from a rural environment and they all go to a public school. One of them had an individual teaching program at school (till the end of the 2017/2018 school year) and is now covered by inclusive education. The other two boys are in a non-inclusion class (there is no inclusion class in the school concerned). According to legal regulations, the choice of school for a child belongs to parents. They can choose between a special school, school with inclusion classes or public school7. In public schools, there is a strong focus on the individualization of requirements and work methods depending on the actual difficulties of respective pupils. It is important that teachers who have children with autism spectrum disorders use simple and unambiguous language, short and concrete sentences without metaphors, idioms, irony or jokes - though these elements are practiced with boys during speech therapy. Each non-verbal signal should be accompanied by verbal information. Apart from that, a teacher, and in particular the form teacher, should try to ensure conditions that would stimu-

${ }^{5}$ A. Hamerlińska-Latecka, Logopedia a metodologia badań nauk społecznych, [in:] Problemy badawcze i diagnostyczne w logopedii, ed. I. Jaros, R. Gliwa, Wydawnictwo Uniwersytetu Łódzkiego, Łódź 2016, p. 19.

${ }^{6}$ A. Banaszkiewicz, Studium przypadku (case study) jako metoda badań logopedycznych, [in:] Metodologia badań logopedycznych z perspektywy teorii i praktyki, ed. S. Milewski, K. Kaczorowska-Bray, Wydawnictwo HARMONIA, Gdańsk 2015, p. 371.

${ }^{7}$ G. Jagielska, op. cit., p. 8. 
late the development of social skills, such as recognizing emotions and learning how to react properly to one's own feelings and emotions as well as those of other people. All teachers should give more time for classwork because of motor disorders and problems with attention focus, and they may also allow pupils to use computers for typing, if need be (one of the boys is allowed to type his homework and longer writing assignments in class on the computer).

Better-functioning persons with autism spectrum disorders are, in their adolescence, more interested in other people and able to create new bonds with peers, though these relations seem superficial and egocentric. Their new friendships are based on common interests, though, in most cases, they see that they stand out from the group ${ }^{8}$. The boys are rarely interested in their peers, they avoid them and do not establish contacts, and if they do, it is not adequate to the situation - they rather demand something, are obtrusive, do not observe the norms and rules and follow their own needs. What is most striking in them, are the difficulties in the reciprocity of communication, they speak to someone, but not talk with someone, they cannot maintain a conversation or social contacts. They often say long monologues that their peers are not interested in. Speech is rarely accompanied by motor stereotypies, the psychologist managed to eliminate them.

The three boys communicate verbally, two of them have no articulatory defects and third is diagnosed with rhotacism. They continue to have some disorders, especially in the sphere of social contacts and interpersonal communication disorders, reluctance to changes, tendency to routine behaviors and stereotypical interests and games. They also have some speech disorders, in terms of the intensity, tone, pace and modulation. The strengths of those pupils include: fast learning, sometimes above-average mechanic memory and talents in the area of visual and spatial skills.

8 J. Komender, G. Jagielska, A. Bryńska, Autyzm i zespół Aspergera, Wydawnictwo Lekarskie PZWL, Warszawa 2014, p. 46-47. 
A speech therapist is not only a specialist on correcting speech defects but also on developing communication skills, especially in persons on the autism spectrum. Then, speech therapy takes place not only in the therapist's office but also outside it: on the corridor, in a shop, at home. Speech therapist instructs a child and his or her parents how to communicate, what to say and when, and what not to say. The therapy with children on the autism spectrum that I conduct as speech therapist together with educator and psychologist covers three areas: understanding the social and emotional perspective of another person, the ability to conduct a conversation and the ability to create peer relationships ${ }^{9}$. Each professional deals with a separate domain, but they need to cooperate and undertake many joint activities. During sessions with a therapist or a group of therapists, boys on the autism spectrum are taught how to communicate (correctly), pay attention when someone else wants to say something or convey a message; not to think about oneself only, not to say something in the wrong time or place. They are trained in conducting conversations with the persons whom they know or who are new to them. Pupils learn what it means to have a friend; they learn to accept the common rules of behavior. A very important element is social skills training ${ }^{10}$ by means of, for example: reconstructing and maintaining self-care skills, establishing and maintaining contacts with people, problem solving, taking care of one's hygiene and aesthetic appearance, money management. During speech therapy sessions, the respective topics are analyzed theoretically, and elaborated from the practical angle in association with the educator and/or psychologist.

Speech therapy puts a strong focus on enriching the vocabulary of pupils by looking for synonyms, antonyms, using dictionaries, explaining metaphors, idioms and polysemantic words. A frequent

${ }^{9}$ M. Piszczek, Autyści. Indywidualne i grupowe metody terapii, Wydawnictwo ES, Warszawa 2014, p. 2017.

${ }_{10}$ Cf. eg.: J.E. Baker, Ilustrowany podręcznik umiejętności społecznych: trening komunikacji, zabawy i emocji dla dzieci z autyzmem, Harmonia Universalis, Gdańsk 2016; C. Gray, Nowe historyjki społeczne, Harmonia Universalis, Gdańsk 2014. 
element of group sessions (together with neurotypical children) are speech therapy games, especially charades, in order to practice using and interpreting mimicry and gestures, and improve social functions.

\section{Three case studies}

\section{$\operatorname{Marcin}^{11}$}

Marcin is 12 years old and he is in grade 5 at primary school. He was diagnosed with child autism at the age of 4 years. He used to go to non-inclusion preschool and he continues education in mainstream school. His educational requirements from the beginning of preschool education were adopted to his individual needs and possibilities. The didactic process is supported by didactic, corrective, compensatory, rehabilitation, speech therapy and psychologist sessions. Marcin's intellectual abilities are below average, his perception skills, linguistic skills, grapho-motor skills and knowledge about social norms are significantly reduced. The boy's therapy (with speech therapist, psychologist and educator) focuses on training his social needs and controlling emotions, cognitive and behavioral therapy, developing behavioral "scripts" and day scheduling. Marcin requires specialist care and therapy, and cooperation of the family and school environment in order to generalize his skills. The rules that the boy should observe, should be the same at home and at school, which is why the cooperation between the school and home environment is emphasized. The purpose of the therapy is to improve cognitive functions and at the same time develop linguistic communication. It is also important to stimulate hearing, visual and motor functions, which helps develop linguistic competencies necessary in the process of communication and playing social roles. Marcin has attended speech therapy since he started his preschool education at the age of 5. At school, he was diagnosed with post-alveolar

${ }^{11}$ The names of the pupils were changed for the purpose of the article. 
consonant disarticulation and rhoticism, which was quickly and successfully eliminated. Currently, he regularly attends 1 hour of speech therapy per week. Speech therapy stimulates the development of his speech and helps him train imitation, which is a condition of social learning. The therapy focuses on creating behavioral "scripts" and then, having mastered a part of material, on verifying the developed, desired behavior in daily life situations, e.g. at the shop, with the janitor, at the canteen, with the school nurse.

Marcin has very good contacts with teachers, he eagerly asks them for help and to explain a difficult issue. His relations with peers are not so good. His classmates do not know about Marcin's disorders, his mother did not want them to be told about the causes of the boy's difficulties. The boy does not have a good friend, he spends the breaks alone, standing by the window. A few years ago, when his older brother went to the same school, he spent the time with him and his colleagues. However, he actively participates in the life of his class and school, he plays football and chess, goes on school trips and green schools and takes parts in competitions and mathematical olympiads. He has particularly highly developed mathematical skills and logical thinking operations. He repeated many times during the conversations that he feels uncomfortable in the classroom and that his classmates are angry with him for his being different. Cooperation with the family often proved to be important here. His mother talks to Marcin, after which his perception of the surrounding reality changes.

Despite being highly independent, the boy does not cope with simple, everyday tasks, like shopping, which is why he attends communication sessions and comprehensive therapy.

\section{Mateusz}

Mateusz is 11 years old and is in grade four. He had an individual teaching program at school from the beginning of preschool education, i.e. when he was 5 years old, until the 2017/2018 school year and since September 2018, he has been in an inclusion classroom. The boy has average intellectual abilities with the supremacy 
of verbal and conceptual thinking over perceptive and executive functions. His working memory is on a very high level as well as his logical thinking on arithmetic material, verbal and conceptual thinking, cause-and-effect thinking on concrete material and sequential memory. His weaknesses include manual and grapho-motor skills as well as visual and motor coordination. Mateusz displays numerous behavioral schemes and a tendency to act routinely, his behaviors are accompanies by stereotypical hand movements, he does not like changes. Sometimes, he has fits of aggression (a few years ago, he was aggressive to teachers and to himself). It is important and even necessary to take care of the boy's integration with his peers. The boy has no friends (because of his early individual teaching program), when asked repeatedly if he wanted to have a friend, he said that his mum was enough for him. However, he experiences lack of peers, e.g. during PE lessons or after school. Teachers introduce lessons in the classroom, also his speech therapy involves group activities. The boy cannot lose, play in a group or share tasks. He has no home chores to do. His mother does everything for him. He is not independent, cannot do shopping, does not go to a hairdresser (hos mother cuts his hair).

His hearing perception is normal, he correctly analyzes and synthesizes phonemes and word syllables. In preschool, he was hypersensitive to sounds, especially those of increased frequency (e.g. the school bell). He was distracted by sounds and too many sound stimuli triggered defensive reactions (Mateusz covered his ears with his hands). In terms of visual and spatial functions, the boy distinguishes geometric figures, can show, draw and reconstruct them. He has problems defining the position of objects in space. He has good visual memory, he notices elements missing from pictures, he reconstructs buildings from a pattern.

Verbal contact with the boy depends on the topic of the conversation and his mood in a given moment. If a therapist raises a topic that the boy is not interested in or does not know much about, he does not continue the conversation, withdraws or changes the topic. At the same time, he speaks eagerly about things that interest him. 
Mateusz communicates with simple and complex sentences, he frequently uses agrarianisms. When he talks spontaneously, he speaks quite fast and unclearly. At the beginning of his therapy, he had wrong intonation and accent, which has improved after six years of therapy. He still uses echolalia and verbal schemes. He has a very rich vocabulary. Mateusz can give word synonyms, explain the meaning of words and give examples of word usage.

During speech therapy, special focus is put on developing linguistic skills. We practice correct naming of things, phenomena, activities, professions, etc., using ready-made picture material, newspapers, the Internet and, most importantly, everyday experiences, e.g. going to the school library, nurse's office, school canteen, secretariat. The boy has problems constructing correct sentences, especially using prepositions. During sessions, he solves numerous puzzles to learn new concepts and their meanings, to create definitions. Mateusz has problems asking correct questions, formulating responses and properly addressing adults - he forgets to call them Mr or Mrs. During therapeutic sessions (also with the school psychologist), he does exercises practicing his social skills that are necessary to function in the school environment. Mateusz has problems focusing on one thing and staying focused for a longer period of time. He wants everything to happen "here and now". He cannot wait for his turn, for his interlocutor to finish talking. In many situations, it is important to make an agreement with him, to find a compromise in order to encourage him to perform a task.

Maciej

Maciej is 16 years old, he goes to grade 3 in junior high school. At the age of 15 , he was diagnosed with qualitative disorders in terms of social interactions, communication and information processing, typical of the Asperger syndrome. The boy has problems making precise utterances and an increased level of anxiety in new social situations. He has average intellectual abilities. His knowledge about the social and natural environment and logical thinking on concrete material are above average, also his visual analysis and synthesis, thinking on 
verbal and conceptual material and visual and motor coordination are slightly above average. He has normal logical thinking on arithmetic material and above-average linguistic skills (knowledge of concepts and their definitions), perception skill and knowledge about social norms. He has problems understanding jokes, metaphors, body language and mimicry of other people. Sometimes, he inadequately interprets his surrounding reality or social situations, which makes him frustrated and anxious. He is hypersensitive to odors and sound stimuli. He does not take and active part in the live of his class or school (school events, assemblies, school outings to the theatre or cinema), because he is afraid of new situations and too much noise, to which he reacts with fear. The teenager does not have major problems in contacts with adults. What is striking about Maciej is that he does not maintain the right distance to adults, he treats them (e.g. his teachers) like his peers, calling them by their first names (the other boys have the same problem), and talks about things that are not supposed to be told to teachers. He is considered "weird" by his class or school mates. He forgets about the right physical distance, he approaches teachers and peers very closely, standing face-to-face, just a few centimeters apart.

He regularly attends speech therapy in and out of school. Therapy helped reduce Maciek's major speech disorders. Currently, the boy has problems with correct articulation of the " $r$ " sound, fluent speech and hypersensitivity of his oral cavity (oral hypersensitivity), which contributes to the development of incorrect reactions. This is accompanied by frequent, intensified emetic reflex, which makes it impossible to maintain the hygiene of the oral cavity and significantly reduces his food intake repertoire. One of the therapeutic methods for Maciej is speech therapy massage and various exercises improving speech fluency.

For desensitization of the oral zone, Maciej receives head area (neck, arms) massage, face (cheeks, temples, chin, mouth area) massage and oral cavity (lips, gums, palate, tongue, cheeks) massage. $\mathrm{He}$ also receives texture stimulation, by touching his face with a brush, fur, "spiky" ball, feather, foil, etc., smell training and articu- 
latory apparatus exercises, focusing in particular on the lips and tongue (mainly erect position). During the sessions, Maciej often interrupts the work, he is overtalkative (talks about topics not associated with the session, often about football), has fits of laughter, he is hyper-agile in the seat area and has numerous hand stereotypies. During speech therapy sessions, often held together with the school psychologist, the boy trains social skills: establishing relations, listening, asking questions, refusing. Maciek learns to start a conversation, discuss politely, react properly to criticism and express criticism. He can name, show, distinguish and express emotions and feelings, but he still needs training emotion handling. An indispensable element of speech therapy (actually, communication therapy) is constant cooperation with the psychologist, because the content of both therapies is complementary and interconnected. The psychologist takes care of the teenager's emotionality, while the speech therapist of his language and communication. At joint sessions, Maciek trains assertiveness in terms of refusing, establishing borders, expressing opinions and feelings without hurting others, coping in situations of rejection by the peer group. He needs continued training in emotions handling, reacting to stress and developing group work skills towards achievement of common goals. The educational requirements are accommodated to Maciek's needs and teachers apply the recommendations in the psychological and pedagogical opinion. In the classroom, there is special focus on pair or group work to enable and stimulate contacts with peers. The form teacher supports the pupil with social contacts in the classroom, encouraging him to accept and perform roles in the classroom community.

\section{Conclusions}

The difficulties that lie at the foundations of the disorders in children on the autism spectrum cannot be removed through training. What is needed is spontaneity, diversity of activities and cooperation of many professionals. If an autistic child is given by 
his or her therapist or teacher adequate space designed especially for him or her, such child will start developing properly and in time may become a partner in dialogue ${ }^{12}$. Work with a pupil on the autism spectrum requires cooperation between teachers, professionals and family, which is confirmed by the case studies. All sessions should follow the same rules and principles, since the inconsequence of even one person involved in the process may cause failure of the therapy.

A necessary element in teaching and caring for a pupil on the autism spectrum is cooperation with parents or legal guardians ${ }^{13}$. They have the most information that can be useful in the teaching process and therapy of the child. Cooperation with parents is necessary in order to get to know the areas of the child's functioning that require support, work and improvement.

The purpose of the article was to characterize the communication between three pupils on the autism spectrum with their peers and teachers, and their daily functioning at school. All the three boys have problems with adequate interpretation of the reality and social situations, which often causes their frustration and anxiety. They do not have major problems in contacts with adults, however, they cannot maintain the right distance to them (e.g. they treat them like their peers and call them by their first names). They are considered "weird" by their class and school mates. They all communicate verbally, though their messages are not always adequate to a situation. Sometimes, they use echolalia and verbal schemes. The boys have very rich vocabulary, though they still do not understand metaphors, jokes or irony. The purpose of speech therapy with pupils with autism spectrum disorders is mainly to achieve communication efficiency on the level that will enable their self-sufficiency and independence. However, therapy sessions are not enough. The rules

12 A. Prokopiak, Niedyrektywność w terapii autyzmu, [in:] Osoba ze stanami ze spektrum autyzmu. Możliwości aktywnego życia, ed. J. Kossewska, Wydawnictwo JAK, Kraków 2014, p. 92.

${ }^{13}$ P. Randall, J. Parker, Autyzm - jak pomóc rodzinie, Gdańskie Wydawnictwo Psychologiczne, Gdańsk 2010. 
determined with the speech therapist must be observed at school, in the classroom, during breaks and at home. Cooperation between professionals, teachers and parents is also important. Only then will it be possible to achieve the desired results.

Autism is not a curable disease. A lot can be done through therapy and progress can be achieved all the time, not only in childhood $^{14}$. However, the sooner therapy starts the better, as the effects of therapy will happen faster, which is the reason why the parents of children on the autism spectrum and the institutions they attend undertake so many initiatives.

\section{Bibliography}

Baker J.E., Ilustrowany podręcznik umiejętności społecznych: trening komunikacji, zabawy i emocji dla dzieci z autyzmem, Harmonia Universalis, Gdańsk 2016.

Banaszkiewicz A., Studium przypadku (case study) jako metoda badań logopedycznych, [in:] Metodologia badań logopedycznych z perspektywy teorii i praktyki, ed. S. Milewski, K. Kaczorowska-Bray, Wydawnictwo Harmonia, Gdańsk 2015, p. 364-379.

Donvan J., Zucker C., Wedtug innego klucza. Opowieść o autyzmie, Wydawnictwo Uniwersytetu Jagiellońskiego, Kraków 2017.

Frith U., Autyzm. Wyjaśnienie tajemnicy, Gdańskie Wydawnictwo Psychologiczne, Sopot 2016.

Gnitecki J., Zarys metodologii badań w pedagogice empirycznej, Wydawnictwo Wyższej Szkoły Pedagogicznej im. Tadeusza Kotarbińskiego, Zielona Góra 1993.

Gray C., Nowe historyjki społeczne, Harmonia Universalis, Gdańsk 2014.

Hamerlińska-Latecka A., Logopedia a metodologia badań nauk społecznych, [in:] Problemy badawcze $i$ diagnostyczne $w$ logopedii, ed. I. Jaros, R. Gliwa, Wydawnictwo Uniwersytetu Łódzkiego, Łódź 2016, p. 19-34.

Jagielska G., Dziecko z autyzmem i zespołem Aspergera w szkole i przedszkolu, Ośrodek Rozwoju Edukacji, Warszawa 2010.

Januszewska E., Januszewska I., Stymulacja rozwoju zdolności i zainteresowań u ucznia z zespotem Aspergera, [in:] Osoba ze stanami ze spektrum autyzmu. Możlizości aktywnego życia, ed. J. Kossewska, Wydawnictwo JAK, Kraków 2014, p. 109-122.

Komender J., Jagielska G., Bryńska A., Autyzm i zespót Aspergera, Wydawnictwo Lekarskie PZWL, Warszawa 2014.

${ }^{14}$ U. Frith, Autyzm, Wyjaśnienie tajemnicy, Gdańskie Wydawnictwo Psychologiczne, Sopot 2016, s. 261. 
Pisula E., Autyzm - przyczyny, symptomy, terapia, Wydawnictwo Harmonia, Gdańsk 2010.

Piszczek M., Autyści. Indywidualne i grupowe metody terapii, Wydawnictwo ES, Warszawa 2014.

Prokopiak A., Niedyrektywność w terapii autyzmu, [in:] Osoba ze stanami ze spektrum autyzmu. Możliwości aktywnego życia, ed. J. Kossewska, Wydawnictwo JAK, Kraków 2014, p. 87-96.

Randall P., Parker J., Autyzm - jak pomóc rodzinie, Gdańskie Wydawnictwo Psychologiczne, Gdańsk 2010. 